\title{
Strategic Parliamentary Dissolution
}

\author{
Kaare Strøm; Stephen M. Swindle
}

The American Political Science Review, Vol. 96, No. 3. (Sep., 2002), pp. 575-591.

Stable URL:

http://links.jstor.org/sici?sici=0003-0554\%28200209\%2996\%3A3\%3C575\%3ASPD\%3E2.0.CO\%3B2-B

The American Political Science Review is currently published by American Political Science Association.

Your use of the JSTOR archive indicates your acceptance of JSTOR's Terms and Conditions of Use, available at

http://www.jstor.org/about/terms.html. JSTOR's Terms and Conditions of Use provides, in part, that unless you have obtained prior permission, you may not download an entire issue of a journal or multiple copies of articles, and you may use content in the JSTOR archive only for your personal, non-commercial use.

Please contact the publisher regarding any further use of this work. Publisher contact information may be obtained at http://www.jstor.org/journals/apsa.html.

Each copy of any part of a JSTOR transmission must contain the same copyright notice that appears on the screen or printed page of such transmission.

JSTOR is an independent not-for-profit organization dedicated to and preserving a digital archive of scholarly journals. For more information regarding JSTOR, please contact support@jstor.org. 


\title{
Strategic Parliamentary Dissolution
}

\section{KAARE STR ØM University of California, San Diego STEPHEN M. SWINDLE Southeast Missouri State University}

\begin{abstract}
$A$
$n$ important agenda power in parliamentary democracies is the discretion over the dissolution of parliament. We argue that variation in constitutional rules and the political environment will systematically affect the frequency of early elections. We hypothesize that dissolution will be more frequent under single-party governments, when the head of state plays an insignificant role, when neither parliament nor the cabinet can inhibit dissolution, when minority governments are in power, when the head of state can dissolve unilaterally, and later in the constitutional term. Using standard logistic and Cox-proportional hazard techniques, we test these expectations in a pooled time-series setting against observations of most OECD parliamentary democracies for the years 1960-1995. We find that parliamentary dissolutions are more frequent earlier in the constitutional term, under minority governments, when the head of state plays an insignificant role, and when the parliament or the cabinet is not involved.
\end{abstract}

I n parliamentary democracies, the accountability of representatives to citizens is established and maintained primarily through legislative elections. Political scientists have paid great attention to such contests and to the popular preferences they signal. A central theme in this vast literature is whether or not (and how) governments are rewarded or punished for their performance-most commonly, their economic performance-while in office (e.g., Anderson 1995a, 1995b; Powell and Whitten 1993; Rose and Mackie 1983). What has been less widely studied, however, is how incumbent politicians use their constitutional dissolution powers precisely to choose the time and circumstances of the voters' reckoning.

Early elections are an option in almost every parliamentary system. Yet the conditions under which this option can be and is exercised vary significantly. Parliamentary dissolution sometimes occurs at the call of a single actor such as the prime minister, whereas in other cases it results from the interaction of several public officials including presidents and parliamentarians. Thus, the politicians whose careers and political fortunes are most directly at stake can frequently manipulate the timing of elections and the conditions under which they occur. Voters and opposition politicians are not blind to this. As a result, the electoral accountability of parliamentary governments is bound up in a series of strategic and anticipatory relationships.

We seek to explain early parliamentary dissolution. There are two potential explanations. Either dissolution occurs because of political need or it happens due

Kaare Strøm is Professor of Political Science, University of California, San Diego, La Jolla, CA 92093-0521 (kstrom@ucsd.edu). Stephen M. Swindle is Assistant Professor of Political Science, Southeast Missouri State University, One University Plaza, MS 2920, Cape Girardeau, MO 63701(sswindle@semo.edu).

The authors wish to thank Scott L. Kastner and Ivy Orr for excellent research assistance. For valuable comments on various drafts, we are indebted to Scott Basinger, Nathaniel L. Beck, Bruce Bueno de Mesquita, John M. Carey, Robert Franzese, Simon Hix, John D. Huber, Arthur W. Lupia, Lanny Martin, Wolfgang C. Müller, Gideon Rahat, the Tuesday Research Group at Brigham Young University, and, especially, Sven Wilson, as well as to the participants and commentators at several conferences at which previous versions of this paper were presented. We remain responsible for any errors or omissions. to political opportunity. In the former case, dissolution could happen with particular frequency during times of crises or in unstable countries. In the latter case, early elections should be held when politicians find them opportune for partisan or personal reasons. We entertain the second possibility. We argue that opportunity is profoundly affected by institutional differences in the strategic environment in which dissolution decisions are made. While it is important to understand the motivations of the politicians empowered to make dissolution decisions, it is just as important to grasp how their opportunities and incentives vary across institutional settings. In exploring these institutional effects, we build on the veto players framework that has become influential in the study of comparative politics (e.g., Tsebelis 2002). Yet a precise understanding of the mechanisms of parliamentary dissolution requires a refinement of that conceptual apparatus.

\section{DISSOLUTION POWERS: A SURVEY}

We take parliamentary government to mean the institutional arrangement in which the chief executive is accountable, through a confidence relationship, to the parliamentary majority and can be removed from office by the latter (Strøm 2000). In most such regimes, simple legislative majorities can dismiss the executive at will on a motion initiated either by the opposition (a successful noconfidence motion) or by the prime minister (a failed confidence motion) (Huber 1996). Most parliamentary democracies also feature a potentially offsetting dissolution power that permits parliament to be retired and new elections to be held before the regular legislative term is up. ${ }^{1}$

This dissolution power is often viewed as a key feature of parliamentarism. Douglas Verney (1959), for example, counts it among the 11 defining characteristics of parliamentary democracy. To Juan Linz (1994), it is a

\footnotetext{
${ }^{1}$ We refer to parliamentary dissolutions and early elections synonymously. Thus, we assume that whenever parliament is dissolved, a general election is constitutionally required and indeed takes place. We thus ignore potential dissolutions followed by states of emergency, coups d'etat, and the like.
} 
critical antidote to the problems of "temporal rigidity" that plague presidential democracies. Parliamentary government is commonly conceived as a system of "fused powers," in which the legislative and executive branches of government are forced to represent consistent policies. When vested in the head of government, the authority to dissolve parliament is a counterweight to the legislative majority's dismissal power. These two "doomsday devices," the dismissal power and the dissolution power, force the legislative and executive branches of government into interdependence (Lupia and Strøm 1995).

Contemporary parliamentary constitutions vary widely in their dissolution powers. There are some systems in which discretionary dissolution is constitutionally proscribed. In Switzerland, which we admittedly would not classify as a parliamentary democracy, parliament can be dissolved only upon constitutional amendment. And while the Norwegian constitution in practice is clearly parliamentary, it permits no early dissolution of the Storting (the Norwegian Parliament) for any reason. Yet such cases are rare. Most constitutions permit parliamentary dissolution and place the ultimate decision in the hands of the head of state, whether monarch or president. In some cases, France and Italy among them, the head of state is constitutionally free to dissolve parliament at his or her discretion. More commonly, however, the head of state can dissolve parliament only upon the request of the prime minister. Yet under some constitutions the prime minister may be able to dissolve unilaterally (as in New Zealand) or with the consent of the parliamentary majority (as in Belgium since 1995). Elsewhere, parliament may, by majority vote, decide to dissolve itself (Austria and, by implication, Sweden since 1975). Several regimes permit or mandate dissolution upon the passage of a constitutional amendment (e.g., Denmark and Belgium). Finally, constitutions sometimes constrain the circumstances or timing of parliamentary dissolution. Many constitutions (e.g., the German Basic Law) seek to reserve this mechanism for emergency situations. The French Constitution does not allow the president to dissolve within the first year of the parliamentary term. And the Italian Constitution permits no dissolution in the last six months of the president's term (the so-called "white semester").

Table 1 surveys the dissolution powers of 20 advanced industrial democracies. We can distinguish among 10 forms of dissolution power, which are not all mutually exclusive. Overall, the variety of dissolution provisions displayed in Table 1 is remarkable. Except for some states in the Westminster tradition, hardly any two parliamentary systems are alike. Some constitutions (e.g., Belgium and Denmark) feature a combination of several dissolution powers. But is this diversity of institutional mechanism purely a curiosity, or does it have systematic and predictable consequences for the ways in which these powers are employed? We argue that differences in dissolution powers indeed affect the incidence of early elections. Our next task is to review our understanding of the behavior that results in parliamentary dissolution, which will enable us to identify the institutional conditions that lead to its occurrence.

\section{EXPLAINING PARLIAMENTARY DISSOLUTION}

Although the literature on parliamentary dissolution is by no means large, recent years have witnessed several interesting efforts to understand the phenomenon and its implications. For example, empirical analyses suggest that Japanese governments may be more likely than Indian ones to dissolve strategically (Chowdhury 1993; Ito 1990). But even more important have been a number of theoretical efforts to understand parliamentary dissolution more generally in "opportunistic" terms. Fundamentally, this body of scholarship has been based on Smith's $(2000,5)$ simple but powerful observation that leaders "call elections when they expect to win." In its most parsimonious form, this assumption has provided the motivation for models that depict parliamentary dissolution as a decision problem faced by a rational and unitary government interested in exploiting its power for electoral advantage. In his pioneering analysis, Balke (1990) thus models the government's decision to call early elections as an optimal stopping problem, assuming that governments maximize tenure in office in a zero-sum world. He finds, among other results, that parliamentary dissolution should be more common when governments enjoy high popularity and when the end of the parliament's regular term (the time at which the constitution mandates that elections be held) approaches.

While the decision whether or not to dissolve may be in the hands of the government incumbents, their behavior may well be conditioned by their interaction with other political actors, such as opposition parties or the voters themselves. To the extent that such actors can affect the benefit that incumbents derive from dissolution, they transform dissolution decisions into games of strategic interaction. Smith (1996) thus analyzes the decision to call early elections in majoritarian systems as a sequential equilibrium game between voters and party (government and opposition) leaders. He assumes that voters use their information about dissolution decisions to update their beliefs about the government's competence and that the opposition devotes resources to a campaign aimed at affecting these perceptions. Ultimately, guided by their perception of the government's competence relative to the opposition, the voters choose whether or not to reelect the government. Given these assumptions, Smith reports, among other analytical results, that early elections are called when the government is popular and when the current value of holding office is low compared to the expected value of future office-holding. The latter might, for example, be the case under a minority government (Smith 1996, 103-04).

Neither Balke nor Smith models governments consisting of a coalition of parties with diverging preferences, the situation that typifies most parliamentary democracies. Lupia and Strøm (1995), however, 


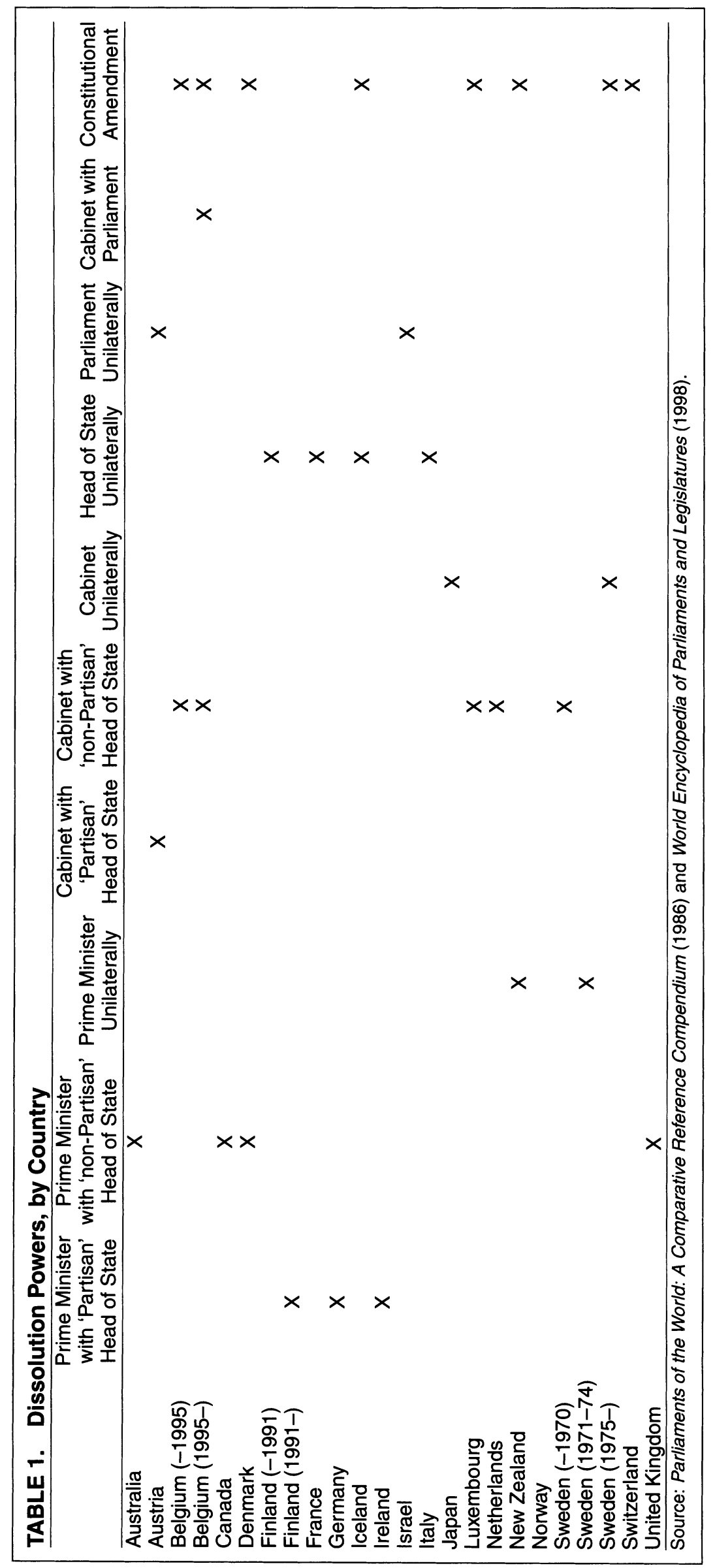


analyze the strategic timing of parliamentary elections in such coalition systems. Their game begins when an event (e.g., a credible poll) informs all parties about their expected fortunes if an election were to be held. Each coalition member can then offer a reallocation of power to any other party. If no party is willing to make an acceptable offer, either there is a vote of confidence in the existing coalition or parliament is dissolved. Lupia and Strøm find that dissolution is most likely when there exist parties that expect large net benefits from an election and at the same time derive little value from the seats they currently control or from coalitions they could enter. Their model also suggests that, all else equal, dissolution becomes more attractive as the end of parliament's constitutional interelection period (CIEP) approaches. Finally, Lupia and Strøm (1995, 655-56) find that dissolution depends on the balance between several types of costs: the opportunity costs of calling elections and the transaction costs of bargaining, campaigning, and electioneering. Diermeier and Stevenson (2000) provide a stochastic reformulation of this model, and in their empirical estimates they separate out the hazard rate due to parliamentary dissolution. Consistently with Lupia and Strøm, they find a substantial increase in the dissolution hazard as the end of the parliamentary term approaches, though empirically this increase is not monotonic.

While this emerging literature rigorously models the motivations behind dissolution decisions, it does not fully capture the effects of the institutional environment. Both Balke and Smith, for example, assume unitary governments that can dissolve parliament at will. This is a considerable simplification of parliamentary democracies, most of which have multiparty cabinets and constitutions that constrain the prime minister's ability to dissolve. Similarly, Lupia and Strøm model dissolution only as a last stage in coalition bargaining and assume that dissolution occurs only when a majority of the legislators prefer that outcome to the status quo. In the real world, however, there is often no coalition bargaining before parliament is dissolved, ${ }^{2}$ particularly if dissolution powers are vested in a single constitutional agent such as the president. ${ }^{3}$ For example, when President François Mitterrand dissolved the French National Assembly in 1981, he deliberately did so against the preferences of the center-right parliamentary majority.

Thus, the existing literature has not adequately captured the institutional rules under which parliamentary dissolution typically happens. Nor has it fully explored

\footnotetext{
${ }^{2}$ The best interpretation of such cases, however, may be that the relevant party leaders bypass the bargaining stage because they correctly anticipate its costs (see above) relative to the expected benefits. In other words, if party leaders perceive a substantial probability of winning an outright majority, they may be unlikely to accept the transaction costs of coalition bargaining and the hassles of actually implementing such a deal. This is particularly likely to happen in majoritarian systems, such as the ones analyzed by Smith.

${ }^{3}$ Nonetheless, the stipulation makes sense as an equilibrium institution, since we would not expect parliamentary majorities to sustain rules under which the legislature could routinely be dismissed against the preferences of its majority.
}

the effects of bargaining between players representing different political parties. Finally, the existing literature remains theoretical and so far has not spawned any extensive empirical investigation. We move forward in all these respects, by considering more complex and plausible institutional environments, by explicitly modeling multiparty situations, and by subjecting our theoretical results to systematic empirical tests. We do so somewhat inductively, by constructing our models on the basis of the empirical survey of dissolution powers reported above.

\section{STRATEGIC DISSOLUTION: A MODEL}

Building on Table 1, let us now consider the circumstances in which parliamentary dissolution powers will be exercised. Presumably, constitution-makers devise dissolution powers to allow politicians to extricate themselves from decisional gridlock, to allow disgraced leaders to retreat, or to permit a consultation with the voters on pressing and unforeseen issues that may arise. Hence, parliamentary dissolution powers are designed to avoid the "temporal rigidity" that Linz (1994) finds to be such a flaw in presidential systems. Yet, like all institutions, dissolution powers can be manipulated for other, and perhaps less lofty, purposes. We are concerned with the ability of politicians to use them for partisan purposes, though we do not deny the possibility of more public-spirited use. Thus, in this section we develop a baseline model of strategic parliamentary dissolution, which we later extend. We model the process that may lead to new elections as a game between three players: (1) the prime minister, whom we assume to be the leader of one of the governing parties, (2) a pivotal coalition partner, and (3) the head of state. We make no assumption here as to whether the head of state holds an elective or hereditary office or whether or not that person is a partisan. We do, however, return to these issues.

Our model assumes that all players are rational and that all the features of the game are common knowledge. We exclude from consideration all dissolutions that are caused by the government's own defeat or collapse. Moreover, we focus on those circumstances in which the options of renegotiating an existing coalition or forming a new one, rather than calling elections, can be disregarded. ${ }^{4}$ The game takes place during the parliament's term, after it has been elected and before its maximum constitutional term (the end of the CIEP) has been reached. The events we describe may be set in motion by a change in one of the relevant payoffs, for example, the expected benefit to one of the parties of holding an election at that time.

We assume that each player has a specific constitutional power and that their interaction occurs in a specified sequence. We agree with Tsebelis $(1995,2002)$

\footnotetext{
${ }^{4}$ In Lupia and Strøm's (1995) terms, this could be because the transaction costs of coalition bargaining are too high relative to the benefits. Compared to Lupia and Strøm, we thus simplify our assumptions about the bargaining environment, while our model is more institutionally contextual.
} 
that the number and preferences of veto players matter. Yet an adequate understanding of parliamentary dissolution requires a careful specification of the decision process and the powers of the individual players. It is useful and indeed necessary to distinguish between powerful players, whose actions may affect the payoffs of other players but whose consent is neither sufficient nor necessary for dissolution; veto players, whose consent is necessary but not sufficient for dissolution; decisive players, whose consent is sufficient but not necessary; and, finally, dictators, whose consent is both necessary and sufficient (Strøm 1995). Moreover, among veto players there may be important differences between those that can exercise agenda control, ex ante veto players, and those that can instead put their feet down ex post.

In our baseline model, the prime minister is a veto player with agenda control. He, and only he, has the power to propose dissolution, and unless he does so, no election will be held until constitutionally required. The coalition partner is a powerful player who has consultative power only. She can dissent from the prime minister's request. After the prime minister has requested dissolution, the coalition partner can choose either to oppose that request or to acquiesce. Finally, the head of state has ex post veto power. Once the prime minister has requested dissolution, and regardless of whether the coalition partner dissents, the head of state can either grant or refuse this request. This baseline model assumes that parliamentary dissolution can take place only when it is initially requested by the prime minister and then approved by the head of state. We later show the implications of varying these institutional assumptions. The extensive form of the game is illustrated in Figure 1. Note that while all three players have some capacity to influence the outcome of the game, they are not all veto players. While the head of state holds an ex post and the prime minister an ex ante veto, the coalition partner is at best a powerful player, who cannot by herself prevent dissolution.

There are five possible outcomes, identified by Roman numerals in Figure 1. Either the prime minister proposes dissolution or he does not. In the latter case, no election is held and the game ends (outcome V). If, on the other hand, the prime minister does call for new elections, the coalition partner has the choice whether or not to oppose this request. If she acquiesces, the game proceeds to the upper subgame at the final decision node, whereas if the coalition partner instead opposes the prime minister's call, the game advances to the lower subgame. Finally, the head of state decides whether to heed or reject the prime minister's request. If the head of state dissolves, the game ends at outcome I (if the coalition partner has acquiesced) or at outcome III (if she has dissented). If, on the other hand, the head of state refuses to dissolve, the result is either outcome II (if the coalition partner has acquiesced) or outcome IV (if she has opposed dissolution).

Before we can solve this game, we describe the payoffs of the players. For each player, there is an expected net value of holding the election now, which we denote $E_{\mathrm{P}}$ for the prime minister, $E_{\mathrm{C}}$ for the coalition partner, and $E_{\mathrm{H}}$ for the head of state. Think of this variable as the difference between the value of holding elections now and the value of continuing the existing parliament, either until its term expires or until some other opportunity for dissolution may arise. We make no assumption as to precisely why the players may or may not prefer a new election. For example, the prime minister may prefer to dissolve because he expects that an early election will allow him to remain prime minister for a longer time, because he believes that his party will get more votes now than at any feasible time in the future, because he anticipates that he may be able to form a more valuable coalition now than later, or for some combination of such reasons.

\section{FIGURE 1. General Model}

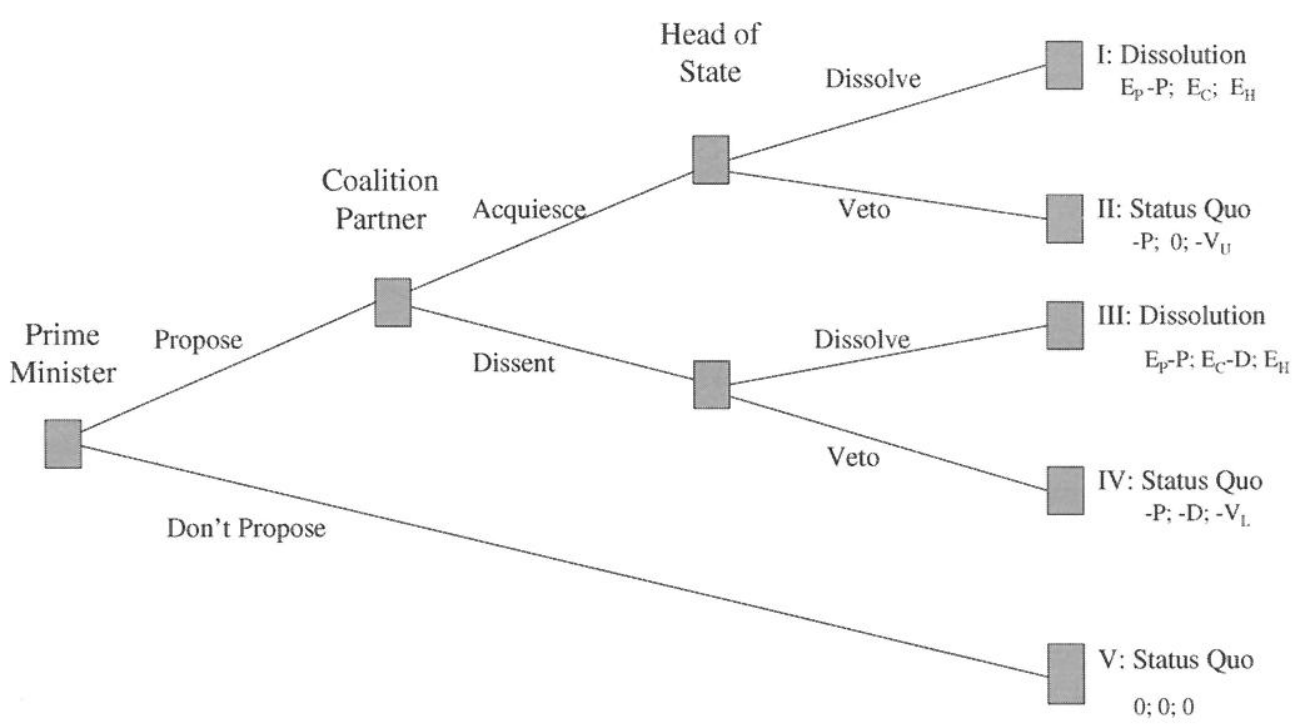


We do assume, however, that to the prime minister and the coalition partner the value of the existing parliament will decline over the course of the parliamentary term. This value derives from two factors: the values of the existing seats and bargaining power that the party enjoys and the value of future opportunities to time elections. With each passing day, the time left in the existing parliament diminishes, and so do the opportunities to call early elections. On the very last day of the parliamentary term, existing seats must be relinquished, and the opportunity to decide election timing disappears. Hence, all else equal, as the value of the existing parliament declines over the course of its term, the net value of holding new elections rises.

\section{Costs}

Each player faces a specific cost associated with the exercise of his or her respective powers. The prime minister incurs a proposal cost, $P$, where $P>0$, whenever he requests an early election. We can think of this as a shorthand for the (unmodeled) signaling game between the prime minister and the voters. As Smith (1996) argues, the prime minister has private information, unavailable to the voters, about the likely future performance of the government and the economy. He can use this information strategically to call elections when he anticipates downturns in the government's fortunes. Unfortunately for him, this very act functions as a signal to the voters that worse times lie ahead. Whenever the prime minister requests dissolution, he thus signals to the voters a lack of confidence in the government's future. The voters will use this information to downgrade their assessment of the government's performance and may respond by withdrawing support from the prime minister's party. We therefore assume that there is always some nonzero cost to such proposals.

The coalition partner pays a dissent cost, $D$, where $D>0$, if she opposes the prime minister's request. Any such expression of dissent amounts to overt conflict within the governing coalition. Awkwardly, this conflict may have to be resolved at the same time that the parties are going into an electoral campaign. The cost of such behavior, again, derives from the voters. All else equal, we believe that voters will downgrade their assessment of governing parties whenever these parties openly squabble. Such squabbles, of course, are likely to be particularly costly when they occur just prior to a general election.

Finally, the head of state pays a veto cost, $V$, where $V>0$, if he vetoes a prime ministerial request for early dissolution. Refusing such a request means picking a fight with the prime minister. Although among parliamentary democracies the head of state's constitutional powers vary, he is typically less powerful than the prime minister. We therefore assume that, all else equal, the head of state will prefer not to frustrate the prime minister. Note, however, that the head of state's veto cost is contingent on the behavior of the coalition partner. If the coalition partner has opposed dissolution and we are in the lower subgame in Figure 1, then the veto cost

\begin{tabular}{lccc} 
TABLE 2. & Payoff Matrix in Dissolution Game \\
\hline \multicolumn{4}{c}{ Coalition } \\
Outcome & Prime Minister & Partner & Head of State \\
\hline II & $E_{\mathrm{P}}-P$ & $E_{\mathrm{C}}$ & $E_{\mathrm{H}}$ \\
II & $-P$ & 0 & $-V_{\mathrm{U}}$ \\
III & $E_{\mathrm{P}}-P$ & $E_{\mathrm{C}}-D$ & $E_{\mathrm{H}}$ \\
IV & $-P$ & $-D$ & $-V_{\mathrm{L}}$ \\
V & 0 & 0 & 0
\end{tabular}

Note: $E_{\mathrm{i}}=$ net expected election benefit for player $i$; $P=$ proposal cost, where $P>0 ; D=$ dissent cost, where $D>0$; and $V_{U}, V_{L}=$ veto cost, where $V_{U}, V_{L}>0$, and $V_{U}>V_{L}$.

is lower than in the upper subgame. In other words, it is less costly for the head of state to refuse a contested request for dissolution than an uncontested one. We denote the former (contested) veto cost $V_{\mathrm{L}}$ (denoting the lower subgame) and the latter (uncontested) veto $\operatorname{cost} V_{\mathrm{U}}$ (denoting the upper subgame).

For simplicity, we assume that no player is indifferent between any of the potential outcomes. Given these assumptions, Table 2 illustrates the payoff to each player under each of the five possible outcomes. Again, all features of the game are assumed to be common knowledge.

We solve the game through backward induction. As the simple proof in the Appendix shows, three of the five outcomes (numbers II, III, and IV) never occur in equilibrium. The coalition partner will never oppose the prime minister's request if she knows that the head of state will dissolve regardless (outcome III). And the prime minister will not propose if he knows that the head of state will veto (outcome II or IV). In equilibrium, we should therefore never observe dissolution requests that are opposed by the prime minister's coalition partner or vetoes by the head of state. This result serves as a caution against interpretations to the effect that even strong heads of state are powerless to refuse dissolution or that parties that do not control the prime ministership cannot prevent the PM from dissolving. One cannot infer the impossibility of such events from their nonoccurrence. Rather, vetoes and intracabinet conflict over dissolution requests fail to occur because the prime minister, or the head of state, anticipates the costs they would impose. The empirical evidence suggests that such "out-of-equilibrium" behavior is, in fact, quite uncommon. ${ }^{5}$ The paucity of contested dissolutions thus suggests that complete

\footnotetext{
5 Occasionally, presidents apparently do consider vetoing dissolution requests, as when German Chancellor Helmut Kohl in 1983 engineered the parliamentary defeat of his coalition on a confidence vote and subsequently requested that Federal President Karl Carstens dissolve. At the time, there was some question as to whether Carstens would indeed comply. Kohl's request was a fairly blatant manipulation of the German Basic Law, according to which the chancellor can request dissolution only when his government has lost its Bundestag majority. Clearly, his parliamentary defeat notwithstanding, Kohl continued to enjoy the confidence of a parliamentary majority. In the end, President Carstens nevertheless acceded to Kohl's request. Yet, over the nearly two decades that have since passed, no other Bundestag has been retired early.

Irish Taoiseach (Prime Minister) Albert Reynolds was less fortunate. In 1993-94 he led a coalition of his own Fianna Fáil and the
} 


\section{FIGURE 2. Special Models 1 and 2}

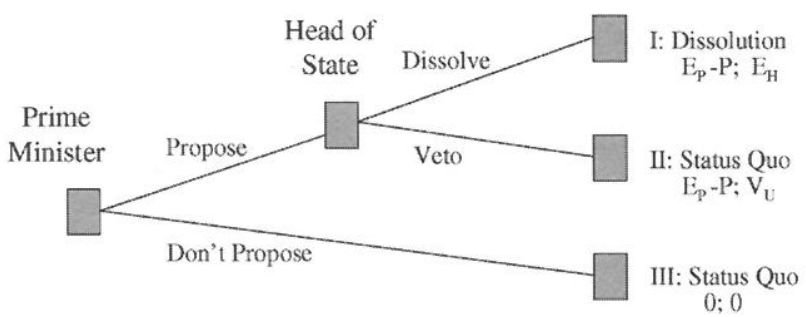

Special Model \#1

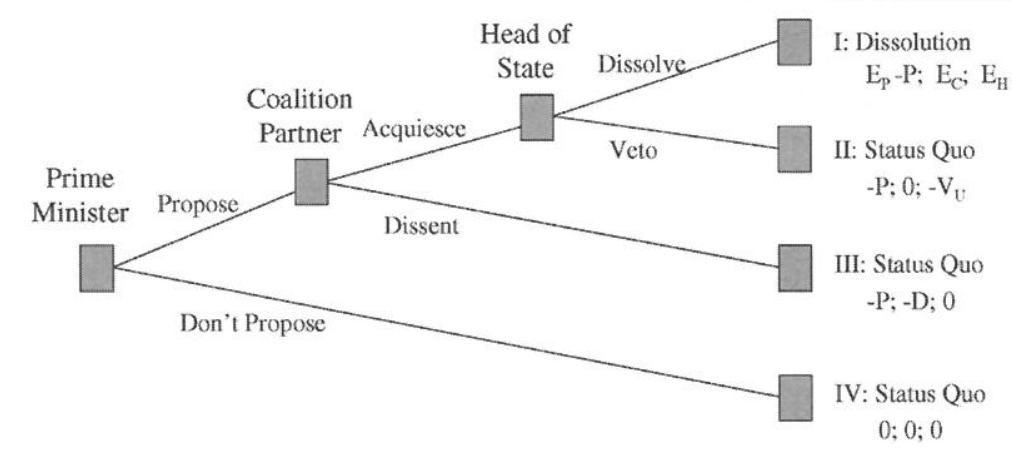

Special Model \#2

information is a realistic assumption for most dissolution scenarios.

Parliamentary dissolution will thus occur if and only if either $E_{\mathrm{P}}-P>0$ and $E_{\mathrm{H}}>-V_{\mathrm{L}}$ (regardless of the coalition partner's incentive condition) or $E_{\mathrm{P}}-P>0$ and $E_{\mathrm{C}}>-D$ and $-V_{\mathrm{L}}>E_{\mathrm{H}}>-V_{U}$. Under all other conditions, the prime minister will not propose and no dissolution will occur.

Given the conditions for dissolution summarized above, simple comparative statics can generate further inferences as to the likelihood of dissolution. For example, all else equal, an increase in the prime minister's, the head of state's, or the coalition partner's expected benefit from an early election could cause parliament to be dissolved when otherwise the status quo would have prevailed. And such increases could never have the opposite effect. Similarly, dissolution may be precipitated by a decrease in the prime minister's proposal costs, or by an increase in the coalition partner's dissent costs or the head of state's veto costs, but never by shifts in the opposite directions.

Irish Labour Party. The coalition collapsed in fall 1994, when Labour withdrew and announced that it would support a no-confidence motion against the rump Fianna Fáil government. Reportedly, Reynolds considered requesting a dissolution of the Dáil (the Irish House of Commons). However, President Mary Robinson then consulted the Chair of the Bar Council on her constitutional powers, which was interpreted as a signal that, if asked, she would veto dissolution (she later told a journalist that she would indeed have refused to dissolve). Thereupon, Reynolds simply capitulated and resigned as Taoiseach and party leader. Instead Ireland had its first-ever change of governing parties without an election. Thus, although dissolution was contested in the Irish as well as the German case, neither president ended up casting a veto.

\section{SPECIAL MODELS}

The model that we have presented does not capture all the real-world institutional variation and complexities. As Table 1 shows, dissolution powers come in many varieties. In addition, they may be exercised in circumstances that do not fully meet the specifications of the model, for example, under single-party governments. Fortunately, a number of these conditions can be captured through simple modifications of our baseline model. In this section, we develop four "special" versions, each of which reflects a common empirical regularity that deviates from the specifications of the baseline model. As we shall see, each special model also generates somewhat different conditions under which parliamentary dissolution will be proposed and undertaken.

\section{Special Model 1: No Coalition Partner}

One special circumstance is when the prime minister has no coalition partner, for example, because he leads a single-party majority government. Then, there will never be a member of the cabinet with a partisan incentive to oppose the request for dissolution. Since the possibility of a contested dissolution proposal is moot, the head of state always finds himself in the upper subgame, and the necessary and sufficient conditions for dissolution reduce to $E_{\mathrm{P}}-P>0$ and $E_{\mathrm{H}}>-V_{\mathrm{U}}$. See Figure 2 for an illustration. In other words, the existence of a suitably motivated coalition partner can, in some circumstances, prevent early parliamentary elections but can never by itself cause dissolution when this would 
not otherwise occur. Parliamentary dissolution thus occurs more easily when there is no coalition partner.

\section{Special Model 2: Proposal Power Vested in the Cabinet/Parliamentary Majority}

The second special model is one in which the coalition partner's approval is necessary for dissolution. Thus, in this model the coalition partner is a veto player, as illustrated in the lower half of Figure 2. We can think of this case as equivalent to a constitution under which the decision to dissolve must be taken by the cabinet as a whole (or by a parliamentary majority). ${ }^{6}$ Austria, Israel, and Sweden feature this variety of dissolution power, though in none of these countries is this the only circumstance in which early elections can be called. ${ }^{7}$ Under special model 2, parliamentary dissolution will occur if and only if $E_{\mathrm{C}}>-D$ and $E_{\mathrm{P}}-P>0$ and $E_{\mathrm{H}}>-V_{\mathrm{U}}$, that is, when indeed the incentive conditions of all three players are satisfied. Thus, this is the only one of the special models in which the necessary and sufficient conditions for dissolution are unambiguously more restrictive than in the baseline model. Hence, if agenda control over dissolution rests with the parliamentary majority, rather than with the prime minister, early elections should be less common.

\section{Special Model 3: A Nonpartisan or Powerless Head of State}

We noted above that in our baseline model the head of state is a generic player. In reality he or she may be either a monarch or a directly or indirectly elected president. As students of parliamentary democracies well know, many such polities, such as the United Kingdom, Spain, Belgium, The Netherlands, and several of the Scandinavian countries, have hereditary monarchs whose preferences (at least those that are publicly expressed) are not driven by electoral considerations. Even under republican constitutions, the president may, for all practical intents and purposes, be a nonpartisan figure, as in Iceland. Nonpartisan heads of state tend to take pains to appear personally disinterested in electoral outcomes.

The constitutional status of the head of state clearly has implications for our model. If the head of state is partisan, then the expected value he derives from early elections will vary with poll numbers and the electoral cycle in the same way as those of party leaders. If, on the other hand, the head of state is nonpartisan, then his net value from new elections should be zero. Our third special model is thus one in which the head of state either

\footnotetext{
6 We treat these two conditions as equivalent. Under minority government, of course, the cabinet may not command the support of a parliamentary majority. In our empirical analysis, we estimate the effect of minority status independently, so that we can control for this divergence.

${ }^{7}$ Note also that under this form of dissolution power, the head of state typically either is nonpartisan or does not enjoy veto powers. Thus, several real-world countries combine special models 2 and 3 . In our empirical model we estimate the effects of these two institutional variations independently, so that it is possible to account for their simultaneous or separate occurrence.
}

is a figurehead or is always indifferent between existing and future parliaments. In this case, we can think of the head of state's incentive condition as satisfied, which means that he will always dissolve if asked. Hence, the coalition partner will not dissent, and dissolution will take place whenever the prime minister's incentive condition is satisfied (i.e., if and only if $E_{\mathrm{P}}-P>0$ ). It is easy to see that this is a more inclusive set of conditions than those that cause dissolution in our baseline model. In other words, to the extent that the head of state's type affects whether or not early parliamentary elections are proposed and held, dissolution occurs more easily under nonpartisan heads of state than under partisan ones. The same logic applies a fortiori to constitutions in which the head of state does not even have any authority to veto dissolution proposals, as in Japan, New Zealand, and Sweden. Here, too, dissolution will occur whenever the proposer's incentive conditions are met.

\section{Special Model 4: The Head of State Can Dissolve Unilaterally}

Finally, our empirical survey tells us that proposal power over parliamentary dissolution need not rest with the prime minister. In several countries, the head of state (empirically in such cases, this is always a president) can dissolve parliament unilaterally. This is true in France, Iceland, and Italy. Until 1991, it was the situation in Finland also. In the fourth and final special model, the head of state is thus constitutionally permitted to dissolve parliament on his own. Since agenda control then rests with the head of state himself, there are no veto costs, and the head of state is effectively a dictator rather than a veto player. The necessary and sufficient conditions for dissolution hence reduce to $E_{\mathrm{H}}>0$. In other words, when the head of state can dismiss parliament unilaterally, dissolution depends strictly on whether his own incentive condition is satisfied. ${ }^{8}$

Note that, compared to the baseline model, this is not unequivocally a more or less restrictive set of conditions. Rather, it substitutes a simple incentive condition for the two conditions in the baseline model. In other words, if the president's incentive condition is satisfied, the prime minister's incentive condition does not bind. On the other hand, unless the head of state favors it, there is no set of preferences on the part of the prime minister and coalition partner that will generate parliamentary dissolution. In the baseline model, the president may dissolve even if his net electoral benefit is negative, as long as his veto costs outweigh this disutility. This will not occur in Special Model 4. On the other hand, in the latter model, the president may have an opportunity to dissolve in situations in which in the baseline model the prime minister would preempt such behavior.

\footnotetext{
${ }^{8}$ The head of state is then either a decisive player (if there are other ways beyond his control in which parliament can be dissolved, e.g. through a constitutional amendment) or a dictator (if there are no such alternative roads to dissolution). In this analysis, we generally disregard the former possibility.
} 


\begin{tabular}{|c|c|c|c|c|c|}
\hline \multirow{2}{*}{$\begin{array}{l}\text { Prime } \\
\text { Minister's } \\
\text { Payoffs }\end{array}$} & \multirow{2}{*}{$\begin{array}{l}\text { Coalition } \\
\text { Partner's } \\
\text { Payoffs }\end{array}$} & \multicolumn{4}{|c|}{ Head of State's Payoffs } \\
\hline & & $E_{\mathrm{H}}>0$ & $0>E_{H}>-V_{L}>-V_{U}$ & $0>-V_{L}>E_{H}>-V_{U}$ & $0>-V_{L}>-V_{U}>E_{H}$ \\
\hline \multirow[t]{4}{*}{$E_{p}-P>0$} & $E_{C}>-D$ & Dissolution & Dissolution & Dissolution & SQ \\
\hline & & & (SM4: SQ) & (SM4: SQ) & (SM3: Dissolution) \\
\hline & $E_{\mathrm{C}}<-D$ & Dissolution & Dissolution & SQ & $S Q$ \\
\hline & & (SM2 \& SM4: SQ) & (SM2 \& SM4: SQ) & (SM1 \& SM3: Dissolution) & (SM3: Dissolution) \\
\hline \multirow[t]{4}{*}{$E_{p}-P<0$} & $E_{\mathrm{C}}>-D$ & SQ & $\mathrm{SQ}$ & $S Q$ & $\mathrm{SQ}$ \\
\hline & & (SM4: Dissolution) & & & \\
\hline & $E_{\mathrm{C}}<-D$ & SQ & $\mathrm{SQ}$ & $\mathrm{SQ}$ & SQ \\
\hline & & (SM4: Dissolution) & & & \\
\hline
\end{tabular}

In Table 3, we summarize the results of the baseline model, as well as each of the special models. All the necessary and sufficient conditions for dissolution can thus be characterized by these 16 mutually exhaustive and exclusive payoff configurations. Note that in the baseline model, five configurations lead to early elections (outcome I), whereas in the remaining 11, no proposal to dissolve will be made (outcome V). In Table 3, we have also identified for each cell the special models in which the result would differ from that of the baseline model.

In the top left-hand cell in Table 3, all three players derive a net benefit from dissolution. Not surprisingly, dissolution occurs under each of our five institutional models. In the cells toward the lower right-hand side, dissolution is much less attractive to the players, and correspondingly there are six cells in which dissolution never happens in any model. The most interesting cells, however, are the shaded set of nine cells running from the top right-hand corner to the bottom left-hand one. These are the conditions under which the preferences of the different constitutional players diverge, and institutional features determine whether or not dissolution happens. In five of these cases, dissolution occurs in one or several special models but not in the baseline model. In four cases, the status quo prevails in one or more special models, whereas the baseline model predicts dissolution. In sum, these results show that (1) there is a broader set of preference configurations associated with the status quo than with dissolution, and (2) there is a large set of conditions under which specific institutional features, rather than preferences in and of themselves, determine the outcome. The first of these results reflects the fact that, overall, dissolution powers tend to constrain, rather than enable, individual constitutional players. The second result suggests that such institutions are both diverse and consequential.

\section{HYPOTHESES}

These results lead straightforwardly to a number of testable hypotheses. As we have seen, the incidence of parliamentary dissolution is determined in part by the preferences of the players and in part by the institutions that may or may not empower them to dissolve. Unfortunately, the preferences of the players, and specifically their electoral expectations, are not directly observable, whereas the institutions are. Many of our hypotheses are therefore derived from the special models and the institutional variation that they reflect. The specific hypotheses that will guide our analysis are summarized below. All should be read as ceteris paribus expectations.

Hypotheses 1 through 4 concern institutional effects that follow directly from the special models.

HyPOTHESIS 1. Except when the head of state has unilateral dissolution power, parliamentary dissolution will be more common under single-party than under coalition governments.

HyPOTHESIs 2. Compared to that in the baseline model, dissolution will be less common when proposal power is vested in the cabinet or in the parliamentary majority.

Hypothesis 3. Compared to that in the baseline model, dissolution will be more common when the head of state is either powerless or nonpartisan.

HYPOTHESIS 4. When the head of state has unilateral dissolution power, the incidence of dissolution will differ from that in the baseline model.

Hypothesis 1 follows from Special Model 1, with the caveat that we expect no effect of coalition status when the dissolution decision rests with the head of state alone. Hypothesis 2 follows straightforwardly from Special Model 2, and Hypothesis 3 similarly from Special Model 3. Hypothesis 4 is the only one that may require a bit of elaboration. Recall from Special Model 4 that when the head of state can dissolve unilaterally, we have countervailing expectations. On the one hand, the president can dissolve even in situations in which the prime minister would not have requested it. On the other hand, an agenda-setting prime minister might request dissolution in situations where the head of state would not have dissolved on his own initiative 
but is unwilling to pay the veto cost. $A$ priori, we have no reason to expect one condition to be more prevalent than the other. This is therefore the only hypothesis that does not specify the direction in which we expect the outcome to differ from the baseline model.

Our next four hypotheses focus on the net electoral benefits, and thus the preferences, of the relevant players. These hypotheses follow less directly from our models but are supported in part by other scholarship on dissolution. Recall that net electoral benefits are the expected benefits from an early election, minus the continuation value of the existing parliament. The latter may differ systematically depending on the type of government in office. Some governments are less capable of controlling the legislative agenda than others and, therefore, less likely to generate effective public policy. Such governments may also more easily be induced to dissolve parliament. The less effective and secure the government is under the existing distribution of parliamentary forces, the lower the value of continuing the existing parliament. Specifically, we expect minority governments to be more frequently persuaded or compelled to call early elections. As Balke (1990, 211-12) points out, "The fact that the government might be forced from power sometime in the future lowers the opportunity costs of losing the election. Thus, governments in parliamentary systems that allow the dissolution of Parliament by a vote of no confidence or systems where coalitions are relatively unstable will call early elections more often" (Smith [1996] makes a very similar argument).

There are actually two reasons to expect minority governments to call early elections more frequently than other administrations: their vulnerability and their electoral prospects. A minority government may easily find itself in a situation in which it has much to gain and little to lose from elections. It might, in such circumstances, dissolve in the hope of significantly improving its bargaining power, for example, by gaining a parliamentary majority, as British Prime Minister Harold Wilson did in October 1974. Both of these factors enhance the expected benefits from an election, relative to current benefits. Since under minority governments the continuation value of the current parliament is thus likely to be low, the net value of new elections should be correspondingly higher.

\section{HYPOTHESIS 5. Early dissolution will be more common under minority governments than under majority gov- ernments (Balke 1990; Lupia and Strøm 1995; Smith 1996).}

An additional consideration is the partisan relationship between the head of state and the prime minister. Special Model 4 shows that when the former has unilateral dissolution powers (is a dictator in this respect), the incidence of dissolution may differ from that in the baseline model, though the expected direction of this difference is unclear. We might, however, in such circumstances, expect differences in partisanship to be a powerful motive for the head of state. He might be more inclined to dissolve if the prime minister represents a different party, compared to when the prime minister is a copartisan. Thus, we expect the interaction of presidential dissolution power and partisan differences with the prime minister to promote dissolution, compared to the baseline model.

HYPOTHESIS 6. When the head of state can dissolve unilaterally, early dissolution will be more common when the head of state is of a different party than the prime minister.

The expected net benefits from an early election also depend on how long these benefits can be enjoyed. This, in turn, is a function of the maximum length of the parliamentary term (the CIEP), as well as of the time remaining in the current term. All else equal, the longer the CIEP, the more likely it is that the net benefits from an early election will be positive. Hence, a long parliamentary term should be positively correlated with the incidence of early parliamentary dissolution. Finally, since the continuation value of parliament will decline over the course of the parliamentary term (see above), the expected net electoral benefits for all players should, all else equal, increase as the end of the constitutional term approaches.

HYPOTHESIS 7. The longer a parliament's constitutional term (CIEP), the more common dissolution will be (see Balke 1990, Lupia and Strøm 1995).

HYPOTHESIS 8. The later in a parliament's constitutional term it is, the more common dissolution will be (see Balke 1990, Lupia and Strøm 1995).

\section{EMPIRICAL DESIGN}

We address these questions by examining all 192 elections in 18 parliamentary democracies from 1960 to 1995 , inclusive. The sample includes most of the world's stable parliamentary regimes and a particularly high proportion of those in Western Europe. We have, however, excluded some states that have not been democratic throughout the $1960-95$ period, such as Greece, Portugal, and Spain. Two additional countries, Switzerland and Norway, have been excluded because neither provides for the constitutional possibility of early elections. See Table 5 for a breakdown of the observations by country. Note that since our sample is relatively small, especially when we break it down into various institutional subcategories, it is difficult to attain conventional standards of statistical significance.

Our analysis occurs in two stages and uses two distinct data configurations. First, we employ standard logistic regression techniques to investigate the frequency of early elections across the countries mentioned above. For this analysis, our observations include all national legislative elections, and the dependent variable is whether or not they were called early. We code as "early" any election that occurs at least 90 days before the end of the constitutional term (CIEP). ${ }^{9}$ We

\footnotetext{
9 The 90-day cutoff divides the sample roughly in half. If a 180-day cutoff date is used instead, the substantive results are quite similar.
} 


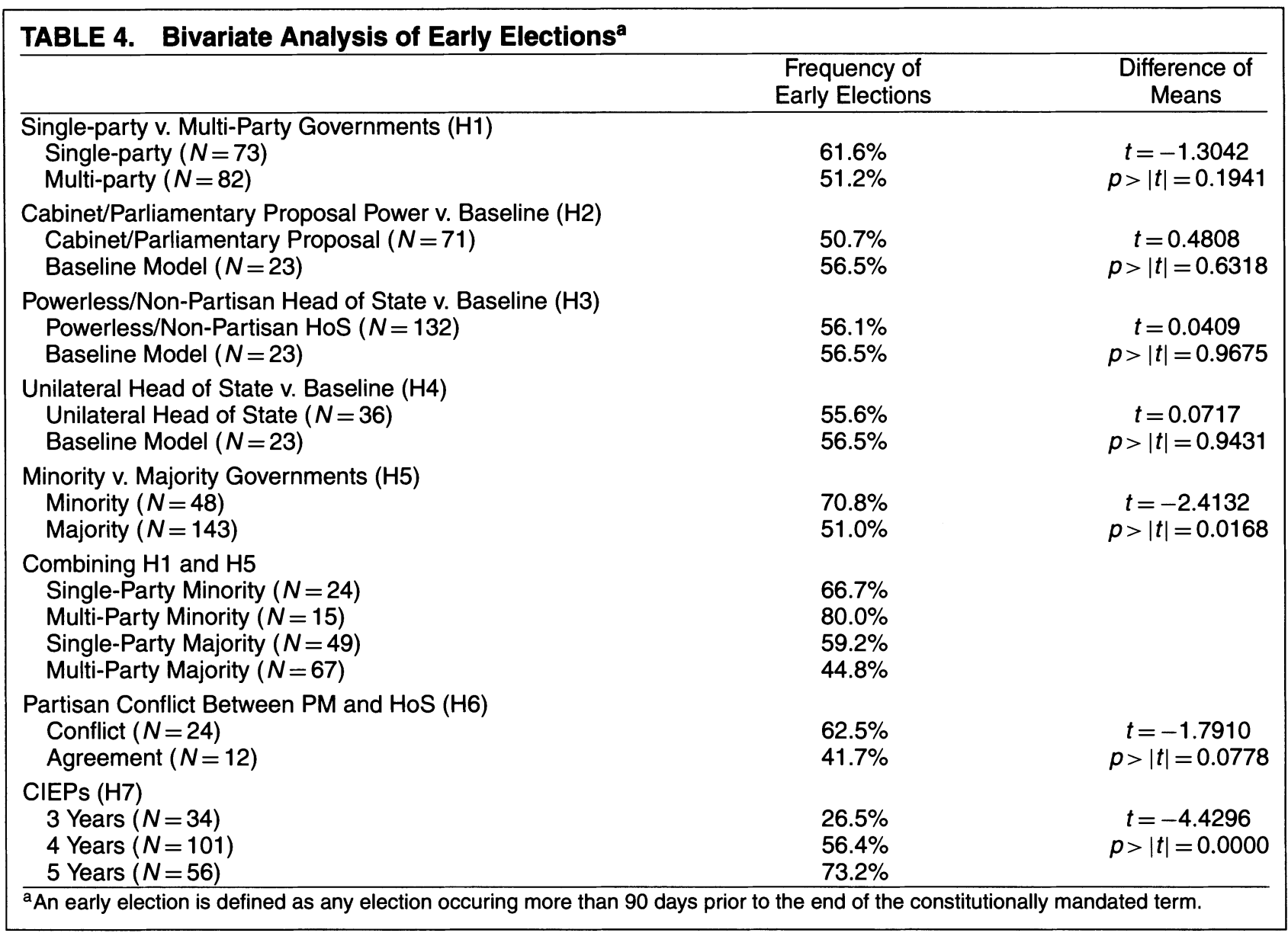

then turn to a duration model to investigate these relationships further. For this portion of the analysis, our units are monthly observations of parliaments, and the dependent variable is whether or not an election was called during that month. For cabinet data prior to 1990 we rely on Woldendorp, Keman, and Budge (1993), whereas subsequent cabinet data have been compiled from Keesing's Record of World Events. Our data on dissolution powers has been drawn primarily from the handbooks Parliaments of the World (InterParliamentary Union 1986) and the World Encyclopedia of Parliaments and Legislatures (Kurian 1998), with supplementary data from personal communication with country experts. For bicameral legislatures, our parliamentary data refer to the lower (popular) chamber.

\section{DO DISSOLUTION RULES MATTER?}

We begin our analysis by examining the effect of institutional rules on the frequency of early elections. Recall that we have four specific hypotheses relating to these issues. First, except in situations where the head of state has unilateral authority, dissolution will be more likely under single-party governments than coalition governments (H1). Second, compared to that in the baseline model, dissolution will be less common when proposal power is vested in the cabinet or the parliamentary majority (H2). Third, compared to that in the baseline model, dissolution will be more common when the head of state is either powerless or nonpartisan (H3). And, finally, when the head of state has unilateral dissolution power the incidence of dissolution will be different from that in the baseline model ( $\mathrm{H} 4)$.

In the top half of Table 4, we report a set of simple bivariate relationships between the variables just outlined and the incidence of early elections. None of the observed differences are contrary to our expectations, though most are statistically insignificant. As expected, single-party governments call early elections more often $(61.6 \%)$ than do multiparty governments $(51.2 \%)$. For hypothesis 2 , our results, though weak, are similarly consistent with expectations. For hypotheses 3 and 4, our first look suggests no effects at all.

We also have four hypotheses less directly derived from these models. First, dissolution will be more likely under minority governments than under majority governments (H5). Second, dissolution will be more common under presidential dissolution control when partisan conflict exists between the head of state and prime minister (H6). Third, dissolution will be more common in countries with longer constitutional terms (CIEPs) (H7). And, finally, dissolution will be more likely as the end of the CIEP approaches (H8).

The simple breakdowns for hypotheses 5 through 7 are presented in the bottom half of Table 4. As 


\begin{tabular}{|c|c|c|c|c|c|c|}
\hline & \multirow[b]{2}{*}{ No. of Elections } & \multicolumn{5}{|c|}{ Percentage of Constitutional Term Expired } \\
\hline & & $>95 \%$ & $75-95 \%$ & $50-75 \%$ & $25-50 \%$ & $<25 \%$ \\
\hline Ireland & 11 & 0 & 5 & 3 & 1 & 2 \\
\hline Denmark & 14 & 1 & 3 & 7 & 2 & 1 \\
\hline Japan & 12 & 1 & 5 & 5 & 0 & 1 \\
\hline United Kingdom & 9 & 1 & 5 & 1 & 1 & 1 \\
\hline Canada & 11 & 2 & 4 & 2 & 1 & 2 \\
\hline Belgium & 12 & 3 & 2 & 5 & 1 & 1 \\
\hline France & 9 & 3 & 3 & 1 & 2 & 0 \\
\hline Italy & 9 & 3 & 4 & 1 & 1 & 0 \\
\hline Australia & 14 & 6 & 3 & 4 & 1 & 0 \\
\hline Austria & 11 & 5 & 4 & 0 & 2 & 0 \\
\hline The Netherlands & 10 & 5 & 3 & 0 & 2 & 0 \\
\hline Israel & 9 & 5 & 3 & 1 & 0 & 0 \\
\hline Finland & 10 & 6 & 3 & 0 & 1 & 0 \\
\hline Iceland & 10 & 6 & 3 & 0 & 1 & 0 \\
\hline Germany & 10 & 8 & 1 & 1 & 0 & 0 \\
\hline Sweden & 12 & 10 & 0 & 2 & 0 & 0 \\
\hline Luxembourg & 7 & 6 & 1 & 0 & 0 & 0 \\
\hline New Zealand & 12 & 11 & 1 & 0 & 0 & 0 \\
\hline Total & 192 & 82 & 53 & 33 & 16 & 8 \\
\hline
\end{tabular}

hypothesis 5 predicts, early elections are called more frequently under minority governments $(70.8 \%)$ than under majority governments $(51.0 \%)$. Yet the interaction between majority and coalition status is particularly interesting. Whereas among majority governments, single-party administrations are more likely than coalitions to dissolve early, the opposite is the case for minority governments, in which case coalition governments call early elections at the impressive rate of $80 \%$. The reason for this reversal among minority governments, we suspect, lies in their vulnerability rather than in strategy. Multiparty minority governments are likely to be the weakest type of parliamentary government, and the high incidence of early elections may reflect their susceptibility to parliamentary defeat rather than strategic and voluntary dissolution on their part.

The results for hypothesis 6 are again in the expected direction. In other words, early elections appear to be more common when the head of state and prime minister represent different parties $(62.5 \%)$ rather than when they are copartisans $(41.7 \%)$. Finally, the expectations of hypothesis 7 are strongly supported, with early elections being called more frequently as the CIEP increases. In countries with a CIEP of three years, only $26.5 \%$ of all parliaments are dissolved early, whereas in countries with a CIEP of four or five years early elections are called $56.4 \%$ and $73.2 \%$ of the time, respectively.

Our final concern here is whether early elections become more common as the parliamentary term wears on. Table 5 lists our countries in declining order of the incidence of dissolution, specifically by the proportion of parliaments dissolved before the 95th percentile of their term. Using a proportional measure for simplicity of comparison, Table 5 also clearly shows that the incidence of parliamentary dissolution increases toward the end of the parliamentary term. Of the 110 parliaments dissolved before the 95th percentile of their regular term, nearly half (53) were in fact dissolved after the three-quarter mark (the 75th percentile). That is, almost as many parliaments were dissolved during that $20 \%$ of their terms than during the preceding $75 \%$ combined. Let us look more closely at this rising rate of parliamentary dissolution. During the first quarter of their terms, no more than 8 of our 192 parliaments were terminated, which amounts to only $4.2 \%$. Over the next quarter of the terms, 16 of the remaining 184 parliaments were dissolved, or $8.7 \%$. The third quarter claims another 33 of 168 survivors, or $19.6 \%$. Finally, 53 parliaments come to an end during the next $20 \%$ of the term, or $39.3 \%$ of the remnant of 135 . Clearly, hypothesis 8 is supported: The later in the term it is, the more likely parliamentary dissolution becomes. In fact, the probability of dissolution roughly doubles with each passing quarter of the constitutional term.

We continue our empirical analysis by reporting a set of multivariate logit models of the frequency of early elections. For this portion of the analysis, the dependent variable equals 1 if an election was called early (before the last 90 days of the constitutional term) and 0 otherwise. The independent variables of model 1 include only those variables directly derived from our special models, along with the CIEP variable. ${ }^{10}$ Specifically, Single-Party Interaction is an interaction between single-party governments and all dissolution rules except unilateral heads of state, taking on a value of

\footnotetext{
${ }^{10}$ The justification for including the CIEP variables in this initial specification is that their effects are constant across the players in our game. Without their inclusion, we believe that the institutional model will be underspecified and that we will not get an accurate picture of the institutional effects.
} 
TABLE 6. Logit Analysis of Early Elections

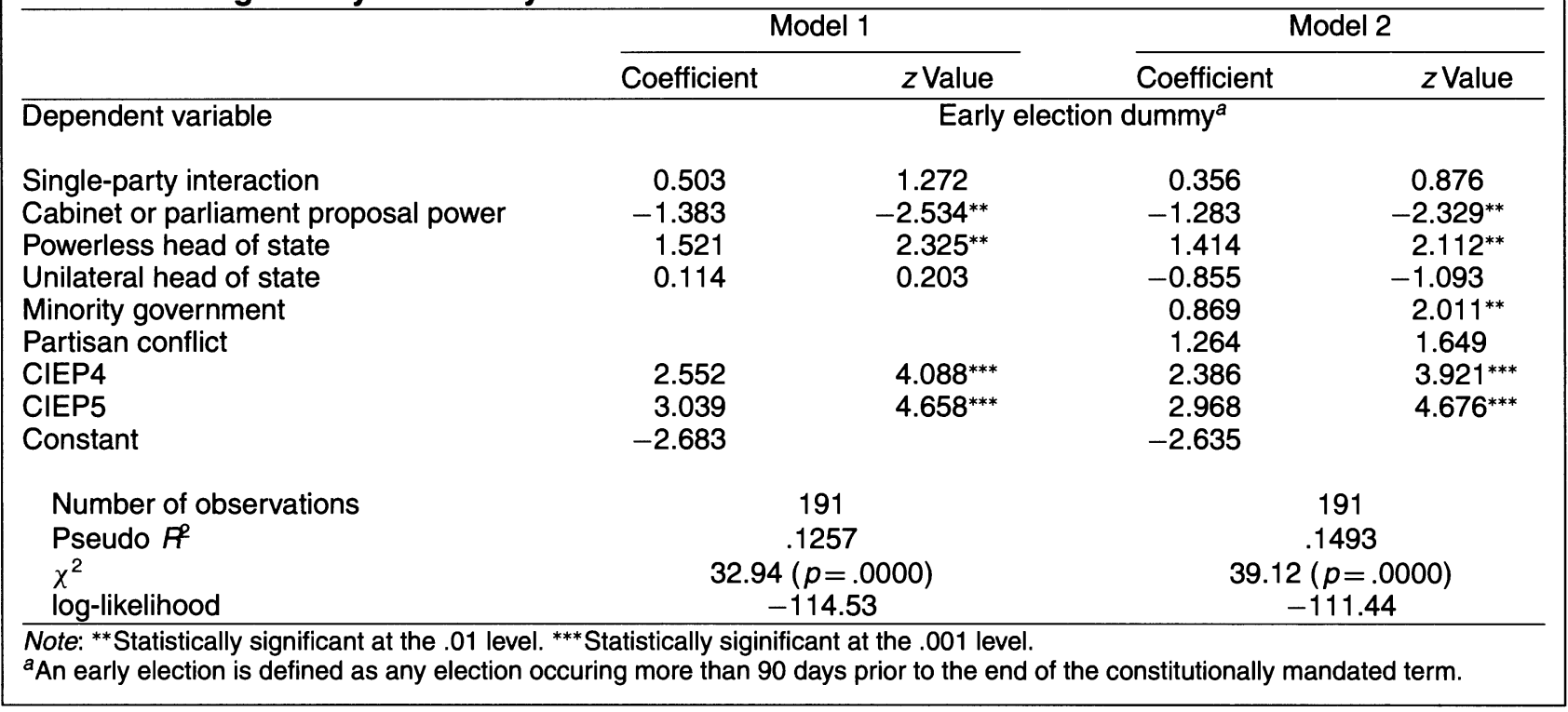

1 when those conditions hold and 0 otherwise; Unilateral Head of State $=1$ if dissolution power is controlled by a unilateral head of state and 0 otherwise; Powerless Head of State $=1$ if the head of state has no role in dissolution and 0 otherwise; Cabinet or Parliamentary Proposal Power $=1$ if dissolution proposal power is controlled by the cabinet or parliamentary majority and 0 otherwise; Ciep $4=1$ if the constitutional term is four years and 0 otherwise; and Ciep $5=1$ if the constitutional term is five years and 0 otherwise. The institutional baseline is effectively equal to our baseline model, whereas the excluded category for CIEP is a three-year term. Model 2 incorporates the two "noninstitutional" variables of our analysis, specifically, Partisan Conflict $=1$ if there is a unilateral head of state whose prime minister represents a different party and 0 if the head of state and prime minister are from the same party, and Minority $=1$ if the government lacks a parliamentary majority and 0 otherwise.

In Table 6, we report the estimates for these two models. The purely institutional model (model 1) clearly confirms that parliamentary dissolution is less common when controlled by the cabinet or parliamentary majority (hypothesis 2). Our expectation that dissolution will be more common with a nonpartisan or powerless head of state is also supported (hypothesis 3 ). As to the effect of a single-party government on dissolution (hypothesis 1), the observed effect is in the correct direction but insignificant. And the effect of having dissolution power unilaterally vested in the head of state (hypothesis 4) is effectively nonexistent. Recall that we had no clear directional expectation concerning this variable because of the potentially countervailing effects of such an institutional arrangement. The results, therefore, may suggest that these effects cancel each other out in the aggregate. Finally, our expectations concerning the effects of term length (hypothesis 8) are strongly confirmed by the two CIEP dummy variables. The longer the constitutional term, the higher the incidence of early dissolution.
When we add the noninstitutional variables to the equation in model 2 , the results of model 1 are reaffirmed. Our estimates of the institutional effects remain unchanged. Among the added variables, minority government enhances the incidence of dissolution, just as we expected (hypothesis 5). The other purpose of model 2 is to try to sort out some of the conflicting effects of vesting dissolution power unilaterally in the head of state. As we expected, the incidence of dissolution goes up when there is partisan disagreement between the president and the prime minister (hypothesis 6). The results also show that, absent such partisan conflict, heads of state are less likely to dissolve than are prime ministers. Yet neither of these effects is statistically significant. In sum, then, no coefficient in either specification of our model has an unexpected sign, even though some of these effects fail to reach conventional levels of statistical significance.

These logistic regression models require us to treat dissolution as a binary variable. For a given parliament, either early dissolution happens or it does not. Yet this is of course a rather crude operationalization, and it is one that does not capture the full force of our argument. It is not just that certain conditions should facilitate dissolution. The likelihood of dissolution should also increase over the course of the constitutional term (hypothesis 7). To test this expectation more cleanly, we conclude our empirical analysis by introducing a simple Cox proportional hazard duration model. Here, our observations are monthly, and the dependent variable is whether or not an election is held during the specific month in question.

The independent variables are identical to those reported in Table 6, with two exceptions. To capture the temporal effects suggested in hypothesis 7 , we have included a time count variable, Time Left, which corresponds to the number of days left in the constitutionally prescribed term (CIEP). Our expectation is there will be a negative relationship between this variable and the incidence of dissolution, which is to say that the more 


\begin{tabular}{|c|c|c|c|c|}
\hline & \multicolumn{2}{|c|}{ Model 1} & \multicolumn{2}{|c|}{ Model 2} \\
\hline & Hazard Ratio & z Value & Hazard Ratio & z Value \\
\hline Dependent variable & \multicolumn{4}{|c|}{ Election term censored } \\
\hline Single-party interaction & 1.367 & 1.251 & 1.208 & 0.801 \\
\hline Cabinet or parliament proposal power & 0.490 & $-2.629^{* *}$ & 0.528 & $-2.641^{* *}$ \\
\hline Powerless head of state & 1.319 & 0.846 & 1.064 & 0.198 \\
\hline Unilateral head of state & 0.665 & -1.219 & 0.434 & $-2.137^{*}$ \\
\hline Minority government & & & 3.365 & $5.572^{* * *}$ \\
\hline Partisan conflict & & & 1.489 & 0.836 \\
\hline Timeleft & 0.997 & $-3.373^{* * *}$ & 0.998 & $-2.807^{* *}$ \\
\hline CIEP4_5 & 4.296 & $2.690^{* *}$ & 3.058 & $2.190^{*}$ \\
\hline Number of observations & \multicolumn{2}{|c|}{7,743} & \multicolumn{2}{|c|}{7,743} \\
\hline $\begin{array}{l}\chi^{2} \\
\text { log-likelihood }\end{array}$ & \multicolumn{2}{|c|}{$\begin{array}{c}22.14(p=.0001) \\
-526.42\end{array}$} & \multicolumn{2}{|c|}{$\begin{array}{c}46.69(p=.0000) \\
-512.64\end{array}$} \\
\hline
\end{tabular}

time is left in the constitutional term, the less likely it is that an election will be called. The introduction of this variable, however, creates severe collinearity problems if we also seek to include both CIEP dummy variables. We have therefore been forced to substitute a single dummy to capture all terms longer than three years. Thus, Ciep4 $4=1$ if the constitutional term is four or five years and 0 otherwise. Finally, because it is impossible to know whether parliaments in the last month of their constitutional term would have been dissolved voluntarily, we have censored all observations within their last month of the CIEP.

Our results, which are reported in Table 7, are broadly consistent with the logistic regression results in Table 6, though in some cases slightly weaker. Again, hypotheses 2, 6, and 7 are clearly supported. In addition, the temporal effect is as we expected: The less time left in the constitutional term, the greater the likelihood of dissolution (hypothesis 8). Moreover, dissolution is, once again, more common under a powerless or nonpartisan head of state, but in these models the effect shrinks to statistical insignificance. Much as in the logit model, the effects of a single-party government are in the expected direction but too weak to be statistically significant. It appears that the expected tendency for single-party governments to precipitate early elections holds for majority but not for minority governments, perhaps because, among the latter, parliamentary vulnerability trumps strategic behavior. Finally, we find the same countervailing but relatively weak effects of vesting dissolution power unilaterally in the president. In sum, we find no results in any of the four specifications of our model that run directly contrary to our expectations. But while some of our hypotheses are consistently supported, other results are not always strong or equal to conventional standards of statistical significance.

\section{CONCLUSIONS}

Polities all over the world are contending with issues of institutional reform. These efforts are based on the explicit or implicit belief that institutions, and the ways in which they structure the policy agenda, matter. We concur. It is therefore surprising that one important institutional mechanism, the authority to dissolve parliament and call early elections, has received such scant attention among political reformers and scholars. Although the power of parliamentary dissolution is a key feature of most parliamentary democracies, it varies substantially from one such system to the next. And even though dissolution powers can be designed to give specific constitutional actors significant agenda powers, there has been very little systematic study of this institution.

Ideally, dissolution provisions can be used to counteract the "temporal rigidity" with which Linz (1994) is so concerned. Yet we have little reason to believe that the actual use of parliamentary dissolution powers is motivated by the need to solve serious political crises. The nations with the highest incidence of early elections, such as Ireland and Denmark (see Table 5), are characterized by vigorous electoral competition rather than systemic instability. Nor does parliamentary dissolution seem to correlate with cabinet instability. The three European countries with the highest rates of cabinet turnover, Italy, Finland, and Belgium (Müller and Strøm 2000, 585), have only middling frequencies of early dissolution. Thus, there is little evidence to suggest that parliamentary dissolution tends to occur in response to systemic crises or parliamentary deadlock. ${ }^{11}$

On the contrary, it appears that the employment of this mechanism can be more plausibly understood as a strategy employed by self-interested or partisan prime ministers or presidents with particular constitutional powers. Such powers are of particular interest to the political observer when they can be used to confer a partisan advantage on those in whom they have been vested.

\footnotetext{
11 Consider the Italian Parliament elected on June 7, 1953. During its term, six successive cabinets were formed, including two that failed their initial vote of investiture. One prime minister, Adone Zoli, found himself dependent on neofascist support and asked to be relieved of his office. His request was refused. Yet no election was called by either President Einaudi (1948-55) or President Gronchi (1955-62) until the end of the regular parliamentary term in 1958.
} 
Our interest in dissolution powers has focused precisely on identifying systematic institutional differences that may affect the frequency with which dissolution powers are exercised for partisan advantage. Building on several recent works in the neo-institutional tradition, we have used a set of simple game-theoretic models to formulate a set of specific hypotheses concerning the effects and strategic use of parliamentary dissolution powers.

Our models show that veto powers, such as may be vested in the head of state, matter. And as Tsebelis (2002) generally suggests, the more veto players, the less likely a change from the status quo (here, a parliamentary dissolution). But not all relevant players are in fact veto players. Some may instead be decisive players or simply (such as the coalition partner in the baseline model) powerful players (Strøm 1995). Decisive or powerful players may also contribute to dissolution, but not necessarily in the same way that a veto player would. To understand parliamentary dissolutions, it is necessary to model the powers of each player carefully.

Our empirical results confirm that institutional rules significantly affect the incidence of strategic parliamentary dissolution. We have found strong evidence that the likelihood of parliamentary dissolution increases substantially and apparently monotonically as the end of the constitutional term approaches. Indeed, the hazard rate of parliaments to dissolution seems to fit an exponential function remarkably well. In examining who dissolves parliament, our strongest results are (1) that dissolution powers are used more frequently by minority governments, (2) that the longer the parliamentary term, the more common is dissolution, and (3) that early elections are less frequent if the power to propose them rests with the cabinet as a whole or the parliamentary majority.

Our analysis supports many of the analytical results of Balke (1990) and Smith (1996). Incumbents do seem to use dissolution powers strategically and for partisan purposes. But we also demonstrate that institutions significantly affect and constrain the ability of incumbent politicians to engage in such timing decisions. The question in constitutional design, then, is what price to pay in partisan opportunism for the flexibility that dissolution powers afford.

\section{APPENDIX}

We here state more fully and precisely the conditions under which parliamentary dissolution occurs in each of our models. The results for the baseline model are presented first, then those of the various special models. We proceed by backward induction and employ the subgame perfect Nash equilibrium solution concept. Please refer to Figures 1 and 2 for an extensive-form representation of the games, to Table 2 for a presentation of the payoff matrix, and to Table 3 for a summary of the equilibrium conditions.

\section{Baseline Model}

Head of State. We first describe the behavior of the head of state at the last stage of the game. In the upper subgame (when the prime minister has proposed and the coalition partner acquiesced), the head of state will dissolve if and only if $E_{\mathrm{H}}>-V_{\mathrm{U}}$. Otherwise, he will veto. In the lower subgame (when the prime minister has proposed and the coalition partner dissented), the head of state will dissolve whenever $E_{\mathrm{H}}>-V_{\mathrm{L}}$ and otherwise veto.

Coalition Partner. We next describe the behavior of the coalition partner at the penultimate stage of the game. Her choices depend on her own payoffs, as well as on her expectations concerning the subsequent behavior by the head of state. For the coalition partner to dissent, two conditions must be satisfied simultaneously: (1) her own incentive condition (she must prefer dissenting and getting the status quo to dissolution), and (2) upon her dissent, the head of state must proceed to veto dissolution. There are three possible configurations of the head of state's preferences: (1) $E_{\mathrm{H}}>-V_{\mathrm{L}}>-V_{\mathrm{U}}$, (2) $E_{\mathrm{H}}<-V_{\mathrm{U}}<-V_{\mathrm{L}}$, and (3) $-V_{\mathrm{L}}>E_{\mathrm{H}}>-V_{\mathrm{U}}$. Only the third of these configurations would satisfy the second condition above. The full set of configurations bearing on the coalition partner's decision, and the related equilibrium conditions in the subgame, are thus as follows.

1. If $E_{\mathrm{H}}>-V_{\mathrm{L}}>-V_{\mathrm{U}}$ and $E_{\mathrm{C}}>-D$, then acquiesce, dissolve (outcome I).

2. If $E_{\mathrm{H}}>-V_{\mathrm{L}}>-V_{\mathrm{U}}$ and $E_{\mathrm{C}}<-D$, then acquiesce, dissolve (outcome I).

3. If $E_{\mathrm{H}}<-V_{\mathrm{U}}<-V_{\mathrm{L}}$ and $E_{\mathrm{C}}>-D$, then acquiesce, veto (outcome II).

4. If $E_{\mathrm{H}}<-V_{\mathrm{U}}<-V_{\mathrm{L}}$ and $E_{\mathrm{C}}<-D$, then acquiesce, veto (outcome II).

5. If $-V_{\mathrm{L}}>E_{\mathrm{H}}>-V_{\mathrm{U}}$ and $E_{\mathrm{C}}>-D$, then acquiesce, dissolve (outcome I).

6. If $-V_{\mathrm{L}}>E_{\mathrm{H}}>-V_{\mathrm{U}}$ and $E_{\mathrm{C}}<-D$, then dissent, veto (outcome IV).

Note that outcome III never occurs in equilibrium in this subgame, because $E_{\mathrm{C}}-D<E_{\mathrm{C}}$, by definition. Hence, the coalition partner will not dissent when she knows that the head of state will not veto.

Prime Minister. Finally, we describe the necessary and sufficient conditions for the prime minister to propose dissolution, as well as the equilibrium in each case. In describing these, we refer to the configurations of preferences of the head of state and the coalition partner by the numbers with which they have been identified above (1 through 6). For the prime minister to propose dissolution, his incentive condition must be satisfied, which means that $E_{\mathrm{P}}-P>0$. Moreover, the prime minister will not propose in any situation that would lead to outcome II or outcome IV, both of which would give him a payoff of $-P$, which by definition is $<0$. In other words, the prime minister will not make any proposal that he knows will be vetoed. Hence, the prime minister will not propose in configurations 3,4 , and 6 above. Thus,

1. If $E_{\mathrm{P}}-P<0$, then not propose (outcome $\mathrm{V}$ ).

2. If $E_{\mathrm{P}}-P>0$ and (1), then propose, acquiesce, dissolve (outcome I).

3. If $E_{\mathrm{P}}-P>0$ and (2), then propose, acquiesce, dissolve (outcome I).

4. If $E_{\mathrm{P}}-P>0$ and (3), then not propose (outcome $\mathrm{V}$ ).

5. If $E_{\mathrm{P}}-P>0$ and (4), then not propose (outcome V).

6. If $E_{\mathrm{P}}-P>0$ and (5), then propose, acquiesce, dissolve (outcome I).

7. If $E_{\mathrm{P}}-P>0$ and (6), then not propose (outcome V).

In summary, there are three payoff configurations that jointly constitute the necessary and sufficient conditions for dissolution (Outcome I), namely, those numbered 2, 3, and 6 above. Thus, dissolution occurs if and only if 
$E_{\mathrm{P}}-P>0, E_{\mathrm{H}}>-V_{\mathrm{L}}>-V_{\mathrm{U}}$, and $E_{\mathrm{C}}>-D$, or

$E_{\mathrm{P}}-P>0, E_{\mathrm{H}}>-V_{\mathrm{L}}>-V_{\mathrm{U}}$, and $E_{\mathrm{C}}<-D$, or

$E_{\mathrm{P}}-P>0,-V_{\mathrm{L}}>E_{\mathrm{H}}>-V_{\mathrm{U}}$, and $E_{\mathrm{C}}>-D$.

These conditions can in turn be summarized as follows: Dissolution will occur if and only if either (1) $E_{\mathrm{P}}-P>0$ and $E_{\mathrm{H}}>-V_{\mathrm{L}}$, or (2) $E_{\mathrm{P}}-P>0, E_{\mathrm{C}}>-D$, and $E_{\mathrm{H}}>-V_{\mathrm{U}}$.

Under all other conditions, no proposal will be made (outcome V). Note that the prime minister prevents any realization of outcomes II and IV, whereas the coalition partner blocks outcome III.

\section{Special Model 1}

In this model, the head of state will dissolve whenever $E_{\mathrm{H}}>-V_{\mathrm{U}}$. Otherwise, he will veto. The prime minister proposes dissolution whenever his own incentive condition is satisfied and he knows that the head of state will dissolve. Hence, dissolution will occur if and only if $E_{\mathrm{P}}-P>0$ and $E_{\mathrm{H}}>-V_{\mathrm{U}}$.

\section{Special Model 2}

In this model, the head of state can dissolve only in what corresponds to the upper subgame of the baseline model, when the prime minister has proposed and the coalition partner acquiesced. As in the upper subgame of the baseline model, the head of state will dissolve whenever $E_{\mathrm{H}}>-V_{\mathrm{U}}$. Otherwise, he will veto.

Special model 2 transforms the coalition partner into a veto player. Yet her choices depend on her own payoffs, as well as on her expectations concerning the subsequent behavior by the head of state. For the coalition partner to dissent, two conditions must be satisfied: She must prefer the payoff from dissent to dissolution (which is to say that $E_{\mathrm{C}}<-D$ ), and she must know that the head of state would not have vetoed regardless. There are two possible configurations of the head of state's preferences: (1) $E_{\mathrm{H}}>-V_{\mathrm{U}}$, and (2) $E_{\mathrm{H}}<-V_{\mathrm{U}}$. The full set of configurations bearing on the coalition partner's decision and the related equilibrium conditions in the subgame are thus as follows.

If $E_{\mathrm{H}}>-V_{\mathrm{U}}$ and $E_{\mathrm{C}}>-D$, then acquiesce, dissolve (outcome I).

If $E_{\mathrm{H}}>-V_{\mathrm{U}}$ and $E_{\mathrm{C}}<-D$, then dissent (outcome III).

If $E_{\mathrm{H}}<-V_{\mathrm{U}}$ and $E_{\mathrm{C}}>-D$, then acquiesce, veto (outcome II).

If $E_{\mathrm{H}}<-V_{\mathrm{U}}$ and $E_{\mathrm{C}}<-D$, then acquiesce, veto (outcome II).

Finally, the prime minister will propose dissolution only if his incentive condition is satisfied, which means that $E_{\mathrm{P}}-P>0$. In addition, the prime minister will not propose if that would lead to outcome II (veto by the head of state) or outcome III (veto by the coalition partner), both of which would give him a payoff of $-P$ (which by definition is $<0)$. Hence, the prime minister proposes only under the first of the conditions above, and the necessary and sufficient conditions for dissolution are $E_{\mathrm{P}}-P>0, E_{\mathrm{H}}>-V_{\mathrm{U}}$, and $E_{\mathrm{C}}>-D$.

\section{Special Model 3}

In this model, the head of state will always dissolve if asked, either because his incentive condition is always satisfied or because he has no power to veto. The coalition partner will then never dissent, since such behavior is costly and could never induce the head of state to veto dissolution. Since the head of state will thus always dissolve and the coalition partner never dissent, the prime minister proposes dissolution whenever his incentive condition is satisfied, that is, if and only if $E_{\mathrm{P}}-P>0$. This, then, is the necessary and sufficient condition for dissolution in special model 3 .

\section{Special Model 4}

In special model 4 , the head of state can dissolve unilaterally and is thus a dictator rather than a veto player. Since agenda control then rests with the head of state himself, there are no veto costs. The necessary and sufficient condition for dissolution hence reduces to $E_{\mathrm{H}}>0$. In other words, when the head of state can dismiss parliament unilaterally, dissolution depends strictly on whether he prefers elections to the status quo.

\section{REFERENCES}

Anderson, Christopher. 1995a. Blaming the Government: Citizens and the Economy in Five European Democracies. Armonk, NY: M. E. Sharpe.

Anderson, Christopher. 1995b. "The Dynamics of Public Support for Coalition Governments." Comparative Political Studies 28 (3): 350-83.

Balke, Nathan S. 1990. "The Rational Timing of Parliamentary Elections." Public Choice 65: 201-16.

Chowdhury, Abdur R. 1993. "Political Surfing over Economic Waves: Parliamentary Election Timing in India." American Journal of Political Science 37 (4): 1100-18.

Diermeier, Daniel, and Randolph T. Stevenson. 2000. "Cabinet Terminations and Critical Events." American Political Science Review 94 (3): 627-40.

Huber, John D. 1996. "The Vote of Confidence in Parliamentary Democracies." American Political Science Review 90 (2): 269-82.

Inter-Parliamentary Union. 1986. Parliaments of the World: A Comparative Reference Compendium. 2nd ed. Aldershot: Gower House.

Ito, Takatoshi. 1990. "The Timing of Elections and Business Cycles in Japan." Journal of Asian Economics 1 (1): 135-56.

Keesing's Record of World Events.

Kurian, George Thomas, ed. 1998. World Encyclopedia of Parliaments and Legislatures. Washington, DC: Congressional Quarterly Press.

Linz, Juan J. 1994. "Presidential or Parliamentary Democracy: Does It Make a Difference?" In The Failure of Presidential Democracy: Comparative Perspectives, eds. Juan J. Linz and Arturo Valenzuela. Baltimore: The Johns Hopkins University Press, 3-87.

Lupia, Arthur, and Kaare Strøm. 1995. "Coalition Termination and the Strategic Timing of Parliamentary Elections." American Political Science Review 89 (3): 648-65.

Mackie, Thomas T., and Richard Rose. 1989. The International Almanac of Electoral History. 4th ed. New York: Facts on File.

Müller, Wolfgang C., and Kaare Strøm. 2000. "Conclusion: Coalition Governance in Western Europe." In Coalition Governments in Western Europe, eds. Wolfgang C. Müller and Kaare Strøm. Oxford: Oxford University Press.

Paldam, Martin. 1991. "How Robust Is the Vote Function? A Study of Seventeen Nations over Four Decades." In Economics and Politics: The Calculus of Support, eds. Helmut Norpoth, Michael Lewis-Beck, and Jean-Dominique Lafay. Ann Arbor: University of Michigan Press.

Powell, G. Bingham, and Guy Whitten. 1993. "A Cross-National Analysis of Economic Voting: Taking Account of the Political Context." American Journal of Political Science 37: 391-419.

Rose, Richard, and Thomas T. Mackie. 1983. "Incumbency in Government: Asset or Liability?" In Western European Party Systems: Continuity and Change, ed. Hans Daalder and Peter Mair. Beverly Hills, CA: Sage.

Smith, Alastair. 1996. "Endogenous Election Timing in Majoritarian Parliamentary Systems." Economics and Politics 8 (2): 85-110.

Smith, Alastair. 2000. "Election Timing in Majoritarian Parliaments." Paper prepared for presentation at the Annual Meeting of the American Political Science Association. 
Strøm, Kaare. 1985. "Party Goals and Government Performance in Parliamentary Democracies." American Political Science Review 79 (3): 738-54.

Strøm, Kaare. 1995. "Parliamentary Government and Legislative Organization. In Parliaments and Majority Rule in Western Europe, ed. Herbert Döring. New York: St. Martin's Press.

Strøm, Kaare. 2000. "Delegation and Accountability in Parliamentary Democracies." European Journal of Political Research 37 (3): 261-89.

Tsebelis, George. 1995. "Decisionmaking in Political Systems: Veto
Players in Presidentialism, Parliamentarism, Multicameralism, and Multipartyism.” British Journal of Political Science 25 (3): 289 325.

Tsebelis, George. 2002. Veto Players: An Introduction to Institutional Analysis. Princeton, NJ: Princeton University Press.

Verney, Douglas V. 1959. The Analysis of Political Systems. London: Routledge and Kegan Paul.

Woldendorp, Jaap, Hans Keman, and Ian Budge. 1993. "Political Data 1945-1990: Party Government in 20 Democracies." European Journal of Political Research 24 (1): 1-119. 
http://www.jstor.org

\title{
LINKED CITATIONS
}

- Page 1 of 2 -

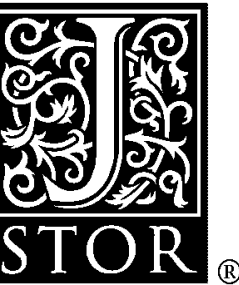

You have printed the following article:

\section{Strategic Parliamentary Dissolution}

Kaare Strøm; Stephen M. Swindle

The American Political Science Review, Vol. 96, No. 3. (Sep., 2002), pp. 575-591.

Stable URL:

http://links.jstor.org/sici?sici=0003-0554\%28200209\%2996\%3A3\%3C575\%3ASPD\%3E2.0.CO\%3B2-B

This article references the following linked citations. If you are trying to access articles from an off-campus location, you may be required to first logon via your library web site to access JSTOR. Please visit your library's website or contact a librarian to learn about options for remote access to JSTOR.

\section{[Footnotes]}

\author{
${ }^{4}$ Coalition Termination and the Strategic Timing of Parliamentary Elections \\ Arthur Lupia; Kaare Strom \\ The American Political Science Review, Vol. 89, No. 3. (Sep., 1995), pp. 648-665. \\ Stable URL: \\ http://links.jstor.org/sici?sici=0003-0554\%28199509\%2989\%3A3\%3C648\%3ACTATST\%3E2.0.CO\%3B2-P
}

\section{References}

Political Surfing over Economic Waves: Parliamentary Election Timing in India Abdur R. Chowdhury

American Journal of Political Science, Vol. 37, No. 4. (Nov., 1993), pp. 1100-1118.

Stable URL:

http://links.jstor.org/sici?sici=0092-5853\%28199311\%2937\%3A4\%3C1100\%3APSOEWP\%3E2.0.CO\%3B2-V

\section{Cabinet Terminations and Critical Events}

Daniel Diermeier; Randolph T. Stevenson

The American Political Science Review, Vol. 94, No. 3. (Sep., 2000), pp. 627-640.

Stable URL:

http://links.jstor.org/sici?sici=0003-0554\%28200009\%2994\%3A3\%3C627\%3ACTACE\%3E2.0.CO\%3B2-E

NOTE: The reference numbering from the original has been maintained in this citation list. 
http://www.jstor.org

\section{LINKED CITATIONS \\ - Page 2 of 2 -}

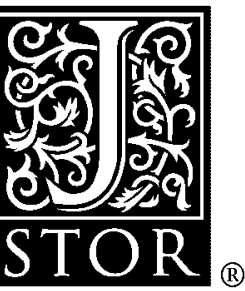

The Vote of Confidence in Parliamentary Democracies

John D. Huber

The American Political Science Review, Vol. 90, No. 2. (Jun., 1996), pp. 269-282.

Stable URL:

http://links.jstor.org/sici?sici=0003-0554\%28199606\%2990\%3A2\%3C269\%3ATVOCIP\%3E2.0.CO\%3B2-Y

Coalition Termination and the Strategic Timing of Parliamentary Elections

Arthur Lupia; Kaare Strom

The American Political Science Review, Vol. 89, No. 3. (Sep., 1995), pp. 648-665.

Stable URL:

http://links.jstor.org/sici?sici=0003-0554\%28199509\%2989\%3A3\%3C648\%3ACTATST\%3E2.0.CO\%3B2-P

A Cross-National Analysis of Economic Voting: Taking Account of the Political Context G. Bingham Powell, Jr.; Guy D. Whitten

American Journal of Political Science, Vol. 37, No. 2. (May, 1993), pp. 391-414.

Stable URL:

http://links.jstor.org/sici?sici=0092-5853\%28199305\%2937\%3A2\%3C391\%3AACAOEV\%3E2.0.CO\%3B2-Z

\section{Party Goals and Government Performance in Parliamentary Democracies}

Kaare Strom

The American Political Science Review, Vol. 79, No. 3. (Sep., 1985)

Stable URL:

http://links.jstor.org/sici?sici=0003-0554\%28198509\%2979\%3A3\%3C\%3APGAGPI\%3E2.0.CO\%3B2-M

Decision Making in Political Systems: Veto Players in Presidentialism, Parliamentarism, Multicameralism and Multipartyism

George Tsebelis

British Journal of Political Science, Vol. 25, No. 3. (Jul., 1995), pp. 289-325.

Stable URL:

http://links.jstor.org/sici?sici=0007-1234\%28199507\%2925\%3A3\%3C289\%3ADMIPSV\%3E2.0.CO\%3B2-J

NOTE: The reference numbering from the original has been maintained in this citation list. 